\title{
Recollections and taxo-ecological studies of Coleochaete scutata Bréb., Coleochaete pseudosoluta Gauthier-Lièvre and Coleochaete conchata Möb., West Bengal, India
}

\author{
Nilu Halder \\ Department of Botany, Raja Peary Mohan College, Uttarpara-712258 \\ Hooghly, West Bengal, India \\ E-mail: niluhalder75@gmail.com
}

\begin{abstract}
The present work had been carried out from Hooghly district, West Bengal, India in order to explore species diversity of the taxon Coleochaete Bréb. of the family Coleochaetaceae under the order Chaetophorales belonging to the class Chlorophyceae. There were some structural complexities and variations among the species. A total number of three species namely Coleochaete scutata Bréb., Coleochaete pseudosoluta Gauthier-Lièvre and Coleochaete conchata Möb. were collected and identified first time from this area. They were described with illustrations and some other valuable information. Shape, size and colour of vegetative and reproductive cells or structures were considered as taxonomic parameters for their identifications. Among them, Coleochaete scutata Bréb. was very common while other two species were rare in occurrence in this district. They are all epiphytes on submerged angiospermic plants. Perusal of cited literatures revealed that the above mentioned species were third time reports from West Bengal, India. Limnological study of water analysis showed that water was weakly alkaline and the aquatic ecosystems were oligotrophic and monomictic types.
\end{abstract}

Key words: Taxo-ecology, Coleochaete Bréb., West Bengal, India.

\section{Introduction}

Algal populations generally grow in water bodies and play significant roles as primary producer and supply energy for all aquatic organisms through aquatic food chains and webs. Recent research activities on algae as biofuel, alternative source of foods or super foods, algal genetic engineering, algae as bio-indicator in water pollution and algal nanobiotechnology etc. are rapidly growing areas in the field of Biosciences which are all developing based on the classical algal taxonomic works (Rai and Rai, 2012).

Coleochaetaceae represented by few genera and is a small family among the freshwater algae in the class Chlorophyceae. Primarily, they are epiphytic on angiospermic plants and sometimes attached on nonliving substratum. Presently, the taxon Coleochaete Bréb. possesses about 16 species and this alga is unique due to its presumed sister position in the evolution of land plants (Szymańska, 2003; Halder, 2015). The molecular and phylogenetic analyses showed that this taxon is monophyletic in origin (Delwiche et al. 2002).

These three species were collected from swampy lands (freshwater ecosystems) at Madhusudanpur and Diara. The two sites were located within Hooghly district, West Bengal, India (Halder and Sinha, 2013; 2014a, b, c). Considering, the complexity and variations of the morphological features among these species and the paucity of information of Coleochaetalean algae from this location, the present work was undertaken. 
Some limnological data of aquatic bodies (temperature, $\mathrm{pH}, \mathrm{NO}_{3}-\mathrm{N}, \mathrm{PO}_{4}{ }^{3-}, \mathrm{K}, \mathrm{DO}, \mathrm{BOD}, \mathrm{COD}$, TDS and $\mathrm{SO}_{4}{ }^{2-}$ ) during sampling time of algal species had been analyzed and exhibited that they were helped for their growth and occurrence.

The previous records of Saxena (1962), Kargupta and Sarma (1991) and Keshri (2010) were produced from West Bengal and by Singh (1941), Venkataraman (1957), Kamat (1962, 1975), Randhawa and Venkataraman (1962), Patel (1968), Prasad and Asthana (1978), Tiwary (1984), Habib and Pandey (1992) and Srivastava and Misra (2009) from India on the taxonomy of those species.

\section{Materials and Methods}

Algal samples were collected in plastic and glass containers from fresh water habitats at Madhusudanpur $\left(23^{\circ} .01^{\prime} \mathrm{N} ; 88^{\circ} .40^{\prime} \mathrm{E}\right)$ and Diara $\left(22^{\circ} .79^{\prime} \mathrm{N} ; 88^{\circ} .28^{\prime} \mathrm{E}\right)$ of Hooghly district $\left(20^{\circ} 30^{\prime} 32^{\prime \prime}-23^{\circ} 1^{\prime} 20^{\prime \prime} \mathrm{N} ; 8^{\circ} 30^{\prime} 20^{\prime \prime}-80^{\circ} 30^{\prime} 15^{\prime \prime} \mathrm{E}\right)$. Detailed taxonomic study was made by examining specimens under Olympus trinocular microscope (Model-CH20i) for descriptions of these species and microphotographs were taken using Canon Power Shot A480 camera. The samples were preserved in $4 \%$ formalin. Identifications of the taxa were accomplished with the help of authentic literatures (Tiffany and Britton, 1952; Prescott, 1962; Printz, 1964; PicińskaFałtynowicz \& Semmerling, 2001; Islam \& Irfanullah, 2005; Srivastava \& Misra, 2009; Keshri, 2010). The $\mathrm{pH}$ and temperature of the aquatic bodies were determined at the sites immediately after collections with the help of portable $\mathrm{pH}$ meter (Model No. PP9046 Philips, India) and Zeal's mercury thermometers (UK). The other limnological parameters such as nitrate-nitrogen $\left(\mathrm{NO}_{3}-\mathrm{N}\right)$, phosphate $\left(\mathrm{PO}_{4}{ }^{3-}\right)$, potassium $(\mathrm{K})$, dissolved oxygen (DO), biochemical oxygen demand (BOD), chemical oxygen demand (COD), total dissolved solids (TDS) and sulphate $\left(\mathrm{SO}_{4}{ }^{2-}\right)$ of waters were estimated by UV-VIS Spectrophotometry (CECIL CE- 7200) following the standard method (APHA, 2005). All the physico-chemical parameters in ecological notes are expressed in $\mathrm{mg} \mathrm{l}^{-1}$ except $\mathrm{pH}$ and temperature.

\section{Results and Discussion}

Three species of Coleochaete Bréb. namely Coleochaete scutata Bréb., Coleochaete pseudosoluta Gauthier-Lièvre and Coleochaete conchata Möbius belonging to the family Coleochaetaceae of the order Chaetophorales under the class Chlorophyceae were described below with author citation, habitat, date of collection, ecological notes, significance and occurrence for the first time from Hooghly district, West Bengal, India. The figure of habitat of Coleochaete Bréb. had also been provided below (Plate 1, Fig.1).

Key to the species

1. Filaments compactly adjoined and forming pseudoparenchymatous monostromatic discColeochaete scutata

1. Filaments not so (2)

2. Filaments loosely spreading; irregularly branched; radiated from a common centre C. pseudosoluta

2. Filaments not so; cells embedded in mucilage; rounded and wavy C. conchata

\section{Taxonomic description}

1. Coleochaete scutata Bréb. in Ann. Sci. Nat. Bot. Ser. 3, 1: 29, pl.2, figs. 1-7, 1844; Tiffany \& Britton, The Algae Illinois 44, pl.10, fig.74, 1952; Prescott, Algae of the Western Great Lakes Area 130, pl.18, fig. 9, 1962; Picińska-Fałtynowicz \& Semmerling in Acta Bot. Cassub. 2: 112, fig. 11, 2001; Srivastava \& Misra in Ecoprint 16: 60, figs.1, 4-5, 2009 (Pl. 1, Figs. 2-3). 
Taxonomic characters: Thallus aquatic, epiphytic, dioecious, heterotrichous, mucilaginous, greenish and circular in outline; 153.0-218.0 $\mu \mathrm{m}$ broad; filaments radiated from a common centre, compactly adjoined and forming pseudoparenchymatous monostromatic disc; cells rectangular, quadrangular to polygonal; vegetative cells $30.0 \mu \mathrm{m}$ long, $20.0 \mu \mathrm{m}$ broad and thick walled; chloroplast single and parietal with one pyrenoid; male thallus large, vegetative cells of male thallus smaller than female one; antheridia grow in groups of 2 to 8; oogonia cone shaped or subglobose; 34.0- $40.0 \mu \mathrm{m}$ long, $24.0-31.0 \mu \mathrm{m}$ broad; spermocarp spherical, corticated and 55.0-88.0 $\mu \mathrm{m}$ in diameter; oospore brownish with smooth wall.

Habitat: In swampy land at Madhusudanpur, Hooghly, West Bengal.

Collection Number and date: NH 349 (10-12-2006).

Ecological notes: Madhusudanpur, water temperature: $20^{\circ} \mathrm{C} ; \mathrm{pH}: 7.0 ; \mathrm{NO}_{3}-\mathrm{N}: 0.1 ; \mathrm{PO}_{4}^{3-}: 0.18$; K: 16.0; DO: 10.0; BOD: 3.4; COD: 90.0; TDS: 132.0; $\mathrm{SO}_{4}{ }^{2-}: 6.2$

Ecological significance: Primary producer in the aquatic body.

Occurrence: Very common

2. Coleochaete pseudosoluta Gauthier-Lièvre in Bull. Soc. Hist. Nat. Afr. Nord. 47: 41, pl. 3, figs 36-38, 1950; Printz in Hydrobiol. 24: 354, pl. 92, fig. 6, 1964; Picińska-Fałtynowicz \& Semmerling in Acta Bot. Cassub. 2: 112, fig. 9, 2001 (Pl. 1, Fig. 4).

Taxonomic characters: Thallus epiphytic, microscopic, mucilaginous, flat and expansion, consists of filaments; filaments loosely arranged; adjoined laterally or not; vegetative cells rectangular to cylindrical, sometimes quadrate; 5.5-10.5 $\mu \mathrm{m}$ broad and 8.5-20.5 $\mu \mathrm{m}$ long; cell wall thick; apical cells with rounded tips or sometimes elongated; chloroplast single, pyrenoid one; spermocarp spherical or sub spherical, corticated, brown; 20.0-30.0 $\mu \mathrm{m}$ broad and 30.-40.0 $\mu \mathrm{m}$ long; oospore 15.0-30.0 $\mu \mathrm{m}$ in diameter.

Habitat: In swampy land at Diara, Hooghly district, West Bengal

Collection Number and date: NH 371(26-12-2006).

Ecological notes: Diara, water temperature: $18^{\circ} \mathrm{C} ; \mathrm{pH}: 7.3 ; \mathrm{NO}_{3}-\mathrm{N}: 0.2 ; \mathrm{PO}_{4}{ }^{3-}: 0.24 ; \mathrm{K}: 20.0$; DO: 8.0 ; BOD: 4.2; COD: 110.0; TDS: 142.0 ; $\mathrm{SO}_{4}{ }^{2-}: 7.4$

Ecological significance: Play significant role as primary producer in the aquatic food chain.

Occurrence: rare

3. Coleochaete conchata Möbius in Flora 75: 426, figs. 6-7, 1892; Printz in Hydrobiol. 24: 356, pl. 3, figs. 5-6, 1964; Islam \& Irfanullah in Bangladesh J. Plant Taxon. 12: 31, pl. 5, figs. 70-71, 2005; Keshri in Alg. Stud. 134: 45, pl. 2, figs. 8-9, 2010 (P1. 1, Fig. 5).

Taxonomic characters: Thallus epiphytic, microscopic, embedded in watery mucilage, prostrate and erect systems not distinguished; filaments radiated from a common centre, loosely arranged, gradually separated from each other towards the periphery of the thallus; centrally located cells are more or less compact and peripheral cells rounded, sub-spherical, angular or pentahexagonal and inflated with wavy margins; vegetative cells 10.5-20.0 $\mu \mathrm{m}$ broad and 14.5-30.0 $\mu \mathrm{m}$ long; apical cells with rounded tips; chloroplast in each cell single, parietal with one pyrenoid; antheridia 6.0-8.0 $\mu \mathrm{m}$ broad and 8.5-10.0 $\mu \mathrm{m}$ long; spermocarp spherical, corticated and 50.0-90.0 $\mu \mathrm{m}$ in diameter; oospore brownish and 30.5-50.5 $\mu \mathrm{m}$ in diameter.

Habitat: In swampy land at Madhusudanpur, Hooghly, West Bengal

Collection Number and date: NH 349 (10-12-2006). 
Ecological notes: Madhusudanpur, water temperature: $20^{\circ} \mathrm{C} ; \mathrm{pH}: 7.0 ; \mathrm{NO}_{3}-\mathrm{N}: 0.1 ; \mathrm{PO}_{4}^{3--}$ : 0.18; K: 16.0; DO: 10.0; BOD: 3.4; COD: 90.0; TDS: 132.0; $\mathrm{SO}_{4}{ }^{2-}: 6.2$

Ecological significance: Primary producer in this aquatic body.

Occurrence: rare

So, the taxonomic study showed species diversity scenario of this taxon from this location while limnological study revealed that water was weakly alkaline in these aquatic bodies and they were oligotrophic and monomictic categories. Therefore, this type of study will be helpful for documentation of algal flora and future algological works from this area.

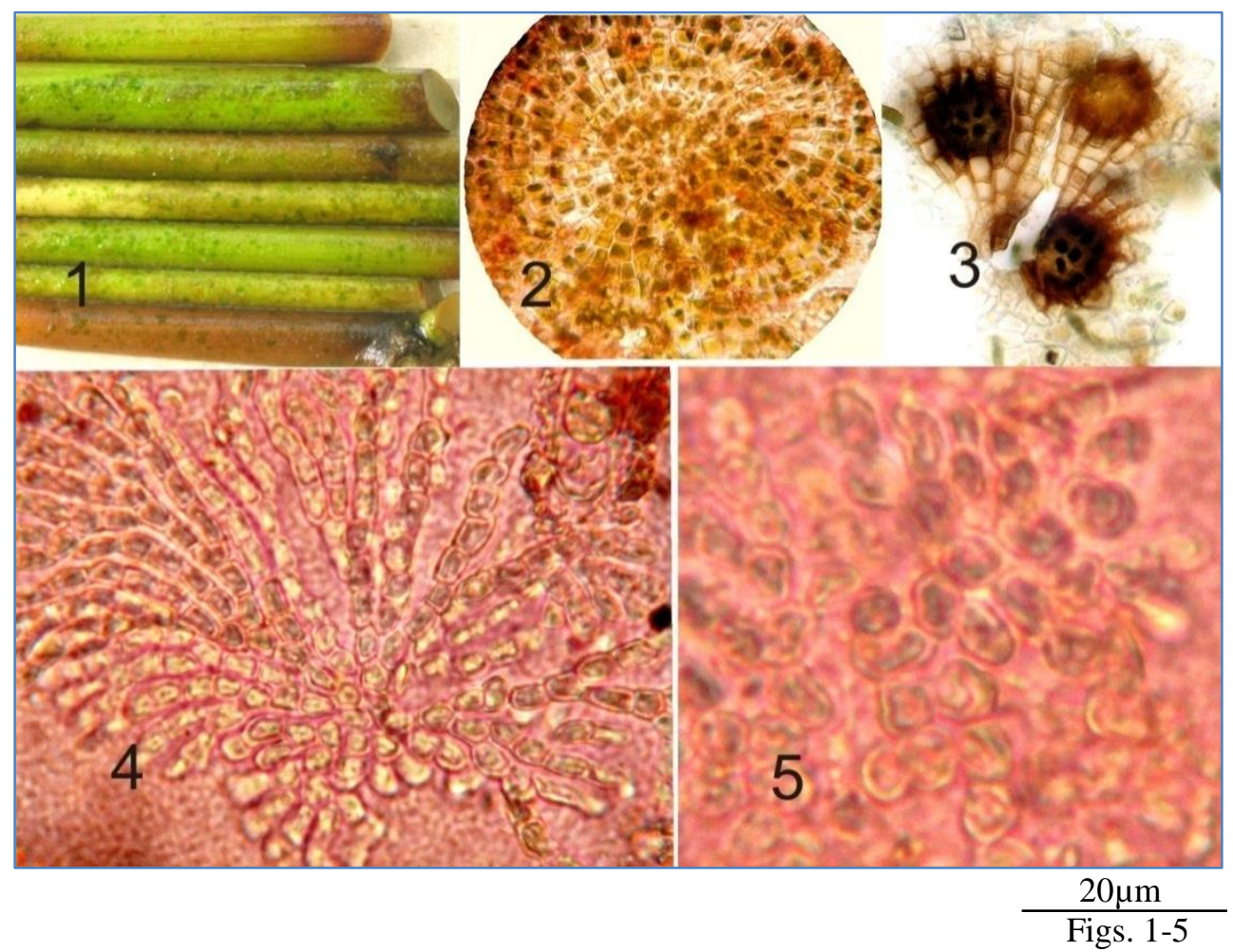

Plate 1: Fig.1. Habitat of Coleochaete Bréb., Figs. 2-3. Coleochaete scutata Bréb., Fig. 4. C. pseudosoluta Gauthier-Lièvre, Fig. 5. C. conchata Möb.

\section{References}

APHA. 2005. Standard Methods for the Examination of Water and Waste Water. (21 ${ }^{\mathrm{st}}$ Ed.), Washington, USA.

Brébisson, A. de. 1844. Description de deux nouveaux genres d'algues fluviatiles. Annales des Sciences Naturelles. Botanique 3: 25-31.

Delwiche, C.F., K.G. Karol, M.T. Cimino \& K.J. Sytsma. 2002. Phylogeny of the genus Coleochaete and related taxa based on the chloroplast gene rbc L. J. Phycol. 38: 394-403.

Gauthier-Liévre, I. 1956. Ulotrichales africaines I. Genres Aphanochaete et Coleochaete. Bull. Soc. Hist. Nat. Afr. Nord. 47: 31-49.

Habib, I. \& U.C. Pandey. 1992. Contribution to our knowledge of Chaetophorales of Madhya Pradesh. Adv. Plant Sci. 4: 150-152. 
Halder, N \& S.N. Sinha. 2013. Diversity of the genera Gloeotrichia Agardh and Rivularia (Roth.) Agardh from Hooghly district of West Bengal, India. Indian J. Fundamental \& Applied Life Sci. 3(3): 2935.

Halder, N \& S.N. Sinha. 2014a.Compsopogon coeruleus (Balbis) Montagne, fresh water Rhodophycean taxa from Hooghly district, West Bengal, India. J. Adv. Sci. Res. 5(1): 32-33.

Halder, N \& S.N. Sinha. 2014b. New Records of Euglena acus (O.F. Müll.) Ehr. and Phacus acuminatus (A. Stokes) Huber-Pestalozzi of Euglenineae from Hooghly District, West Bengal. JAIR. 3(7): 333-336.

Halder, N. \& S.N. Sinha. 2014c. New report of Dichotomosiphon tuberosus (A. Br.) Ernst and Vaucheria sessilis D.C. of the family Vaucheriaceae from Hooghly district, West Bengal, India. Ecoprint 21: 49-53.

Islam, A.K.M.N. \& H.M. Irfanullah. 2005. Hydrobiological studies within the tea gardens at Srimangal, Bangladesh: III. Chlorophyceae (excluding Desmids). Bangladesh J. Plant Taxon. 12(2): 19-37.

Kamat, N.D. 1962. Chlorophyceae of Ahmedabad, India. Hydrobiol. 20: 248-279.

Kamat, N.D. 1975. Algae of Vidarbh, Maharashtra. J. Bombay Nat. Hist. Soc. 72: 450-476.

Kargupta, A.N. \& P. Sarma. 1991. New records of Coleochaete species, from West Bengal, India. Bangladesh J. Bot. 20(2): 149-156.

Keshri, J.P. 2010. Contribution to our knowledge of Coleochaetales (Chlorophyta) of West Bengal, India. Alg. Stud. 134: 41-54.

Möbius, M. 1892. Australische süsswasseralgen. Flora 75: 421-450.

Patel, R.J. 1968. On Coleochaete from Gujarat (India). Phykos 7: 90-97.

Picińska-Fałtynowicz, J. \& A. Semmerling. 2001. Epiphyticalgal flora on Lobelia dortmanna L. in lake Dobrogoszcz (Kaszubskie Lake District, Northern Poland). Acta Bot. Cassub. 2: 97-122.

Prasad, B.N. \& D.K. Asthana. 1978. Coleochaete pseudosoluta, a new addition to the Indian flora. Curr. Sci. 47(5): 176.

Prescott, G.W. 1962. Algae of the Western Great Lakes Area. $2^{\text {nd }}$ ed. Brown Co., Dubuque, Iowa. 977p.

Printz, H. 1964. Die Chaetophoralen der Binnenge wässer. Hydrobiol. 24: 1-376.

Rai, S.K. \& R.K. Rai. 2012. Some interesting freshwater algae from Chimdi lake including a new record for Nepal. Nepalese J. Biosci. 2: 118-125.

Randhawa, M.S. \& G.S.Venkataraman. 1962. Notes on some Chaetophorales from India. Phykos 1: 4452.

Saxena, P.N. 1962. Algae of India I. Chaetophorales. Bull. Nat. Bot. Gard. 57: 1-59.

Srivastava, A.K. \& P.K. Misra. 2009. Coleochaete Breb. and Bulbochaete Agardh from North-Eastern Uttar Pradesh, India. Ecoprint 16: 59-63.

Szymańska, H. 2003. Coleochaete spalikii Szymanska sp. nov. (Charophyceae, Chlorophyta) -a new member of the Coleochaete sieminskiana group. Nova Hedwigia 76(1-2): 129-135.

Tiffany, L.H. \& M.E. Britton. 1952. The algae of Illinois. Chicago University, Chicago. 407p.

Tiwari, R.K. 1984. Coleochaete conchata Möb. (Chlorophyta): A new record from India. Curr. Sci. 53(6): 321-322.

Venkataraman, G.S. 1957. The algal flora of ponds and puddles inside the Banaras Hindu University grounds, India. J. Bombay Nat. Hist. Soc. 54: 908-919. 